This is a pre-print draft version of a published article. To cite this article, see:

Helen Macnaughtan (2014) The Oriental Witches: Women, Volleyball and the 1964 Tokyo Olympics, Sport in History, 34:1, 134-156, DOI: 10.1080/17460263.2013.855651

To link to this article: http://dx.doi.org/10.1080/17460263.2013.855651

\title{
The Oriental Witches: \\ Women, Volleyball and the 1964 Tokyo Olympics
}

At the 1964 Tokyo Olympics, the Japanese women's volleyball won the gold medal, which in many ways can be viewed as an epoch-making event in Japanese post-war sporting history. I explore the background to that victory, revealing a corporate history of the sport with a prominent role played by Japanese cotton textile companies. I argue that gold medal success at the 1964 Olympics is the result of a history of corporate investment in women's volleyball, in particular by one company, Nichibo Corporation, and I tell the Olympic story with a focus on the personal recollections of the women's volleyball team captain, Kasai Masae. Finally, I evaluate the impact that Olympic victory had on the popularity and strength of women's volleyball in Japan in the decades after 1964.

\section{A Corporate History of Women's Volleyball in Japan}

While playing in a volleyball tournament for her high school team in 1951 one girl, Kasai Masae, was scouted by a representative of Nichibō Corporation, and subsequently recruited into the company to play for their team. Nichibō was at that time one of the Big Ten cotton spinning corporations in Japan and had established a reputation for having a strong volleyball team. Like many sports that are popularly played in Japan today, the playing of volleyball had developed over time within an institutional context. Sport has been and continues to be strongly encouraged in educational institutions, but also within corporations in Japan. In the case of women's volleyball, there is a notable historical link to the cotton textile industry in Japan, which can be traced back to a century ago, and it can therefore be described as a 'corporate sport' in terms of its origins and history. The history of women and sport in Japan is a growing field of scholarly interest, and serves to not only document the overlooked history of female participation in sport in Japan but also to shed light on the implications it has for the broader debates on gender in Japan. ${ }^{1}$ The gold medal victory in women's volleyball at the 1964 Olympics has been noted as an important event in Japanese sporting history by several scholars writing on sports history in Japan, but there remains scope for further exploration of the corporate history behind this victory and the gender dynamics that can be drawn from this story. ${ }^{2}$

Volleyball was initially developed in large Japanese cotton spinning companies based on paternalistic management attitudes vis-à-vis their core workforce of young female employees. With hundreds of thousands of young women in their employ, these large companies led the way in establishing key employment strategies aimed at managing not only a large but a distinctively female workforce. Alongside factory-based employment strategies, they invested in various facilities for their workers including dormitory accommodation, schools and education, and sports and recreation activities. This investment was based on early ideas 
of corporate responsibility for the broader 'wellbeing' of workers. ${ }^{3}$ Sport and recreation activities developed alongside key educational initiatives as a way not only of keeping young girls busy and occupied during non-working hours within factory residential compounds but also as a way of promoting the physical health of workers. The sport of volleyball was introduced by textile companies as it offered the chance to encourage team work amongst young female workers, required minimal equipment and could be played both indoors and outdoors. Over time the increased popularity and indeed strength of these female corporate teams from the large Japanese textile companies became notable, and developed into an investment beyond mere recreation.

Kanebō, now famous for producing cosmetics but historically a textile firm, was the first among the large Japanese cotton textile companies to introduce volleyball as a recreational activity for employees in 1913, while the firm Kurabō was known to have held a company tournament for its various factory volleyball teams as early as 1918. By the 1930s female factory-based teams from amongst the large-scale textile firms were competing in volleyball tournaments against teams from girls' schools. ${ }^{4}$ From a social perspective this is interesting, as girls employed in the textile companies were predominantly from poor rural families across Japan while those in the girls' schools were primarily of an elite urban class. Stigmatised at this point in Japanese social history as 'factory girls' (jokō), the volleyball court must have offered opportunities for these young women in the textile teams to interact with girls outside their social class, and no doubt provided the big textile firms an opportunity to redefine their image as employers which was something they were keen to pursue, having been criticised for their exploitation of young female workers in Japanese throughout their pre-war history.

The 1920s was the decade in Japan when national sporting championship tournaments including those at middle and high school level began to flourish, and industrial or corporate sporting leagues strengthened. Many Japanese national sporting federations were established from the 1920s including the Japan Volleyball Association (JVA) in 1927, and these national federations also sought and attained recognition from international sporting federations during these years. ${ }^{5}$ Baseball was the most popular sport for men and boys in Japan at this time, while volleyball gained momentum as a key sport for Japanese girls. Domestic volleyball tournaments were halted during the war years in 1943-45, but started again in 1946 as the sport continued to flourish after WWII. In 1951 the first Japanese national volleyball championships was held, and 25 of the 50 competing teams were factory-based teams from the main Japanese cotton textile companies. These included six teams from Kanebō, five teams from Nichibō, five teams from Kurabō, three teams from Toray and two teams from Tōyōbō. ${ }^{6}$ The presence of textile teams was notable at the championships and supports the view that by the 1950s volleyball was a competitive sport rather than a recreational activity within these textile companies. Moreover, the hegemony of the sport in Japan had gradually moved from girls' schools to the cotton spinning corporations. ${ }^{7}$

Volleyball as a sport was growing in popularity after WWII, not only in Japan but worldwide. The International Volleyball Association was established in 1947, and the world championships were held the first time for men in 1949 and for women in 1951, but at this point in time limited only to European countries. A decade later, in 1959, the International Olympic Committee (IOC) decided that men's volleyball was to be an Olympic sport. In 1960, Japan for the first time sent both a male and female team to the world championships, held that year in Brazil. The Japanese men's team took eighth place, but the women's team unexpectedly won second place in the world competition. This Japanese women's team, 
rather than being a national team, was in actual fact a corporate team from Nichibō's Kaizuka factory; at that time the strongest women's team in Japan as winners of the domestic national championships. The Japan Volleyball Association (JVA) had limited funds at this point to fund two teams go to Brazil in 1960 and so had encouraged Nichibō to fund their Kaizuka women's team's trip to the world championships to see what the international competition level was like. After winning second place in Brazil, Nichibō subsequently decided to fund the team on a European expedition in 1961, where they went on to play and win 24 consecutive games. ${ }^{8}$

The Nichibō Kaizuka team was coached by a man called Daimatsu Hirofumi. Born in Kanagawa prefecture in 1912, he entered employment at Nichibō in 1941 after graduating from Kansai Gakuin University, having played volleyball at both high school and university. However, shortly after joining Nichibō he was called up by the Japanese army and during WWII fought in China, Burma and Rabaul. A survivor of these notorious battlefields, he later commented that his wartime experience had a profound effect on his life. Rejoining Nichibō employment after the war ended, he was chosen in 1953 to become the manager of the then newly created Nichibo Kaizuka women's volleyball team, and charged with selecting potential players for the Kaizuka team from some 3,000 girls in teams across the company's employment. Daimatsu went on to coach this team for the next twelve years, establishing its reputation as the strongest women's volleyball team in Japan of that era, and was subsequently chosen to coach the women's Olympic team for the 1964 Tokyo Games.

Daimatsu became infamous for his highly disciplined and strenuous training regime for his volleyball players and was nicknamed 'Demon Daimatsu' (Oni no Daimatsu) by the Japanese media. His instructive phrases used during training sessions at Nichibō were later immortalised in the titles of his own publications: 'follow me' (ore ni tsuitekoi) and 'if you try, you will succeed' (naseba naru). He did not like his female players to lose strength or take days off from volleyball training due to their menstrual cycles and instructed his players to forget about being a woman during training. Conscious that any of the female players could be menstruating during key tournaments, Daimatsu took the view that players should always aim to play at their physical best. This was radical at the time as Japan had a long history of 'motherhood protection' (bosei hogo) in its labour history, and in the 1947 Labour Standards Law was the first country to include menstrual leave for working women. ${ }^{9}$ Daimatsu devised several techniques for volleyball play after observing the Japanese women's team defeat at the hands of the Soviet team in 1960 in Brazil. His variety of new techniques included moves such as: 'move and attack' (idō kōgeki), 'falling leaves serve' (konohaochi sābu) and 'time lag attack' (jikansa kōgeki). But his most infamous move was the technique known as 'receive and rotate' (kaiten reshìbu) which became the signature move of the Nichibo Kaizuka team. Given the difference in physical stature between the Japanese and USSR women's teams, Daimatsu believed that agility and speed were the key to defeating the Soviet champions, and so he devised a move, often likened to a jūdo move in nature, whereby a player could receive the ball without touching their bottom on the floor and then rotate immediately into a defensive position. This 'receive and rotate' was a difficult technique to master. Some players damaged their spine and kidneys as their bodies hit the floor hard during the learning process. After the Tokyo Olympics, the 'receive and rotate' technique became an aspirational skill amongst young female high school volleyball players to the extent that some Japanese schools prohibited its use when it led to incidents of broken collarbones. Increasingly in the media spotlight after the win in Brazil in 1960, Daimatsu wrote two books, the titles of which were taken from his training instructions: 'Follow Me!' published in 1963 and 'Where there's a Will, there's a Way' published in 1964. During his 
twelve year stint as coach of the Nichibō Kaizuka team they were the strongest volleyball team in Japan, winning 175 consecutive games. Later in his life, Daimatsu reflected that his training regime and techniques had indeed been harsh, but also commented that volleyball was not about physical techniques alone and required a 'fighting spirit' (konjō). In the buildup to the Tokyo Olympics, Daimatsu's training techniques steadily gained attention both nationally and internationally, and his training regime was documented in a short film, that later won Grand Prize at the 1964 Cannes Film Festival. ${ }^{10}$

The story of the 1964 Olympic gold medal victory in women's volleyball for Japan can be told from both a media and historical perspective, but I would argue that it is also the personal story of an extraordinary team - that of Coach Daimatsu and the captain of that women's gold medal team, Kasai Masae. ${ }^{11}$ Kasai became captain of the Nichibō Kaizuka women's volleyball team in 1957. Born in Yamanashi prefecture in 1933, she first started playing volleyball at school in 1946. She recalls that she had joined the volleyball team because she had thought the team advisor, a teacher at the school, was 'good looking'. ${ }^{12}$ She was later spotted by the Nichibō rep when her volleyball team was playing in a Kanto tournament, because she was very tall for a Japanese woman at that time $(174 \mathrm{~cm})$ and displayed potential on the court. ${ }^{13}$ A representative from Nichibo subsequently came to her parents' house offering her employment in the company. Kasai describes her parents as being overwhelmed and thankful for a visit from such a big corporation. Her parents accepted the company's offer, and she describes it as 'like a dream' because Nichibō had the number one volleyball team in Japan at that time. ${ }^{14}$ In Spring 1952, aged 18, she graduated from high school and entered Nichibo employment, initially recruited into the company's Sekigahara factory in 1952, but moved a month later to the Ashikaga factory, which had the company's strongest volleyball team at that time. In 1953, Nichibō decided to unite all its factory teams and establish a new corporate team at their Kaizuka branch, so she was moved to Kaizuka in $1954 .{ }^{15}$ This creation of the Kaizuka corporate team was a strategy to conquer in Japanese domestic competition, and the Nichibō Kaizuka team indeed went on to become the strongest national team for the next decade. Volleyball training was intensified in line with this strategy, and a training regime known as 'murderous exercise' (satsujin taisō) was implemented by Daimatsu from this time. ${ }^{16}$

Kasai did not work on the factory floor in alternating patterns of shift-work like the majority of young females working for Japanese textile companies including Nichibō at this point in history. Instead she did a 'desk' job and from 3pm daily she and her team mates would attend several hours of volleyball practice in the company gymnasium. Kasai and other volleyball players would have stood out from the core group of female employees at that time. ${ }^{17}$ Although company employees, they clearly evolved to become sports women and it was no doubt difficult to regard them as being within the mainstream female workforce. Kasai describes how at the Kaizuka factory she used to share a dormitory room with two other 'regular' female employees. ${ }^{18}$ When she came back from volleyball training late at night the others were already in bed but they used to make up the (futon) bed for her so she could just get into it, and on cold winter nights would also have put a hot water bottle in her bed. When she woke in the mornings, her roommates had already cleaned the corridor and gone to their work shift, but she was permitted to get up later than them because of her late night training and would start her work shift after tidying up and cleaning the room. ${ }^{19}$ Kasai describes how she appreciated her roommates' kindness and thoughtfulness and felt that she had to practice hard as a volleyball player for them. 
Prior to the 1960s, the key goal of the Nichibo team was to be the best women's team in Japan, although there was a foray toward international competition when Kasai was one of three Nichibō players selected to go to China in 1957 to play six-a-side volleyball for the first time (prior to that nine-a-side volleyball had been played in Japan). ${ }^{20}$ However, after Kasai and her team-mates took second place in Brazil in 1960, the stakes changed. With their sights set on the next international championships scheduled for Moscow in 1962, Kasai comments that after returning from Brazil, she and her team mates began to train for longer hours than before, from $3 \mathrm{pm}$ in the afternoon until 2 or 3 am every day. With Daimatsu at the helm, they had their sights firmly set not only on maintaining their status as the number one team in Japan, but potentially becoming the number one team in the world.

When questioned why Nichibō was so much stronger in volleyball than the other textile companies at that time, Kasai was modestly reticent, simply suggesting that because they did the most practice, they became the strongest team. Given Daimatu's notorious approach to training this no doubt greatly contributed to Nichibō success in volleyball, but there was a concrete corporate strategy to be found behind this. Nichibō, like other Big Ten cotton companies, first introduced in-house sports as a recreational activity for young female employees in their factory and dormitory compounds from the late Meiji and early Taisho years. While other cotton companies noted the benefits that recreational sport could bring in terms of improving worker well-being, Nichibō appears to have gone further than other companies in terms of utilising sports to develop desirable attributes in their employees. Volleyball, basketball, softball and other 'cultural' activities such as camping were used by the company to foster and develop skills such as camaraderie, responsibility, leadership, discipline and teamwork, all deemed to be vital for young females who were both working and living together for several years and were the 'paternal' responsibility of Nichibō. In the early post-war years this was further extended as, faced with a labour market shortage, growing competition from other sectors who also sought to employ young women, and a poor historical image relating to their long employment of 'factory girls' (jokō), the textile companies used both education and sporting opportunities as a recruitment pull. Nichibō, in particular, went even further with this tactic, not only developing volleyball teams and clubs across all its factories but using their recruiting agents to scout skilled volleyball players, picking the best players from across the company to join their 'headline' Kaizuka team and employing dedicated coaches such as Daimatsu. ${ }^{21}$ Increasing dominance in corporate sporting events could also be used for corporate publicity. Success in domestic volleyball competitions against rival cotton companies boosted Nichibō's corporate pride and was a strategy used not only to develop and integrate employee skills (which could translate into improved workplace productivity and boosted sales) but also to help promote the company image and be used as a PR tool. ${ }^{22}$

The impact of Nichibō's focused investment in the sport of volleyball is impressive in its sporting track record alone. During her time as captain, Kasai and her team mates played and won 185 consecutive games, and after she retired, the Nichibō Kaizuka team continued to win until its 258th game. I would suggest that some of their success lay in the fact that Nichibō took key initiatives in scouting and recruiting strong players into their employment, just as Kasai herself was recruited. However, it is certainly also true that the Kasai-led team were dedicated in their practice, under the formidable leadership of Daimatsu. Kasai commented in interview that she and the team were happy to take direction from him, despite the well reported severity of his training regime, because they trusted him. She commented that he had a 'great human nature', and that she herself held a lot of trust and respect for him as a person, but that there was also a close bond between him and the team. Kasai said that 
every time their team won, they were further convinced that his hard training regime was right, and were all prepared to practice hard again in order to win again. Daimatsu's relationship with his players was extremely strong. None of the players have ever said anything negative about him in any interviews. ${ }^{23}$ I would argue that much of the Nichibō team's winning streak can also be attributed to Kasai. When asked in interview why she was chosen as captain of the Nichibo in 1957 and subsequently for the Olympic team, she states that it was because she was the eldest player. Noting that the next eldest player was four years younger than herself, she laughingly suggested that the other team members were therefore 'afraid' of her. However, she then went on to state that the other members of the team were great, because they made considerable efforts to unite themselves around her and there was good team work. When I asked whether she might have been chosen as captain because she was the strongest player, she laughingly refuted this suggestion, confirming again that it was because she was the eldest. ${ }^{24}$ However, she did go on to say that because she played in the 'setter' position she did have the ball most often. What is certain, is that as captain of the Japanese women's volleyball team for the 1964 Tokyo Olympics, she would become one of the most famous personalities in Japanese sporting history.

\section{The 1964 Olympic Gold Medal Victory for Japanese Women's Volleyball}

Tokyo was awarded the rights to host the 1964 Games at an IOC meeting in May 1959. This was historically significant for two reasons. Tokyo had been due to host the 1940 Summer Olympics, but due to Japan's invasion of China this right was instead passed to Helsinki, and later cancelled altogether due to WWII. ${ }^{25}$ Japan was not invited to London in 1948 for the first post-WWII Games. Second, the 1964 Tokyo Games were the first Olympics to be held in Asia. Less well known in history is that this was the first Games to include women's volleyball. Although the Olympics had long comprised individual sports for women, women's ball games and team sports were played for the very first time at the 1964 Games. The granting of the Olympics to Tokyo was very symbolic for Japan. It represented an international 'acceptance' that Japan was back on the post-war world stage, and reflected the fact that the country had 'risen from the ashes' of WWII in under 20 years to be able to host the Olympics and be seen as a leading modern, technological nation.

The reconstruction of Japan's infrastructure, massively destroyed during WWII, was still in progress when Japan was awarded the Games. Getting ready to host the Olympics involved a massive investment in new architecture and infrastructure on Tokyo's part. This included improvement of train and subway lines, construction of an elevated highway system and a monorail airport link, modernisation of both Haneda International Airport and the Port of Tokyo, as well as the launch of the bullet train (shinkansen) - the fastest train in the world at that time, opened just ten days before the opening ceremony. The Tokyo Olympics also recorded many firsts in terms of both technology and in the history of the Games. It was the first time that Olympic events were broadcast internationally in colour for television using a satellite relay system. Computers were also used for the first time to record the outcomes and statistics of that Olympics. It can also be said that it was the first time that the Games were visually coordinated, with the first use of pictograms to represent sporting events and the first use of photography in Olympic posters and art. State of the art Japanese technology for that era not only helped to streamline the games and relay them around the globe, but it signified to the international audience that 'Japan was back'. 
The Tokyo games played an important role in uniting the Japanese public behind the event and restoring national identity and 'spirit' after wartime defeat. At the opening ceremony, on $10^{\text {th }}$ October 1964, the Olympic Flame was lit by Sakai Yoshinori, who had been born in Hiroshima on $6^{\text {th }}$ August, 1945, the day the atomic bomb was dropped on that city. Various events during the games - the appearance of the Japanese Emperor, the singing of the national anthem (Kimigayo), the use of the Red Sun (Hinomaru) flag, and the use of the Self Defence Forces to guard the Olympic village, transport athletes and help coordinate sporting events - all served to redefine and reintegrate at that time 'taboo' symbols of war which could now be used to project a new peaceful Japan to the world. ${ }^{26}$ The artwork for the Games was bold and modernist for the time, with the red sun, symbolising Japan, pictured above the five Olympic rings. As one Japanese scholar, a primary school pupil at the time of the Olympics, commented:

\footnotetext{
The date, 10 October 1964, was thus marked in the minds of many ordinary Japanese as the beginning of Japan's 'rise'. And this 'rise' was imagined communally through the images of athletic bodies, which we watched through the mediation of TV cameras, and through the stories that were brought to us by the media en masse. The narratives of individual athletes were told in such a way that they would draw forth in the viewers a sense of national unity and pride in an autonomous nation. ${ }^{27}$
}

The hosting and portrayal of the 1964 Olympics was viewed as vitally important by the Japanese government. Although key events of the Games were usually recorded on film by the IOC, the Japanese government chose to finance their own film, which resulted in the film Tokyo Olympiad. ${ }^{28}$ Considered a milestone in documentary film-making for its time, it concentrated on portraying the atmosphere and human side of the athletes, instead of focusing only on the results and medallists. In results alone, it would be a highly successful Games for Japan, with 16 gold medals (and a total of 29 medals) placing it third in medal rankings behind the USA and the USSR in $1964 .{ }^{29}$ Both the rising medal tally and rising pride built up throughout the games, 'unifying' the nation. The opening ceremony was watched by over $70 \%$ of the Japanese viewing public, but by the time the women's volleyball final was broadcast on 23 October, a day before the closing ceremony, this event set a record high with a viewing audience of $85 \% .^{30}$

After setting their sights on winning at the 1962 world championships, held in Moscow in October 1962, the Japanese women's team again met the Soviets in the final, and in a surprise upset beat the Soviet world champions. After that victory, the Japanese team was given the nickname 'The Oriental Witches' (Tôyo no Majo), coined by the Russian media in the newspaper Pravda, commenting that the Japanese team had used some form of 'magic' in their victory. Although a 'witch' (majo) is a frightening concept in Japan, Kasai commented, when asked about the nickname in interview, that she and her team mates did not take offence at the nickname and that it had simply been used by the Soviets to describe the 'magic' of the Japanese play, which had included never before seen techniques devised by Daimatsu, such as 'receive and rotate'.

Kasai and others in the team had originally intended to retire after the Moscow championships, because of their age. The eldest in the team, Kasai was 29 years old when she played in Moscow. However, when it was announced in April 1962 that women's volleyball would be an Olympic event for the first time at Tokyo, the team were questioned by the Japanese media. Kasai recollects that she was decisive in her response at that time, stating that she had already decided to retire after Moscow later that year. However, after their victory in Moscow, Kasai comments that she felt persuaded from all corners to continue 
playing and aim for the Olympics. She records that this was not an easy decision given her age and the hard training that would lie ahead between 1962 and 1964, by which time she would be 31 years old. However, the public expectation was immense, and the team received some 5,000 letters from fans urging the 'Oriental Witches' to continue. In early 1963, the team members got together after the New Year holiday, and most of the players decided to stay until the Olympics. Kasai decided to give up her ambitions to marry for the time being and to aim for the gold medal at the Tokyo Olympics. ${ }^{31}$ In interview, Kasai recollected that she decided to continue because she felt that the public at that time would 'not allow her to retire', and that the only way to respond to the public's expectation that the national team could win the gold medal was to try and give them that victory.

Despite his strict and 'demon like' reputation, Daimatsu clearly felt a strong sense of personal and paternalistic responsibility for his female players. Conscious that they could only endure a few years of his harsh training regime, as well as conscious of their ages, Daimatsu had intended to retire after the 1962 world championships, thereby allowing his players the opportunity to also retire and be free to potentially get married. When questioned by the media in 1962, Daimatsu commented that although he was confident that they could win the Olympics in two years time if all players continued, many players were of marriageable age, and thus he could not comment on the team's viability for the Tokyo Olympics. ${ }^{32}$ However, as noted, there was immense pressure for the in-situ team to continue, not least from the Japanese Olympic Committee, who were reluctant for such a winning team to disband. Daimatsu agreed to stay another two years as coach of the national women's team until the Olympics. After these decisions in 1962, Kasai recalls Daimatsu instructions to his team: ${ }^{33}$

"We have two years, so let's do the very best that we possibly can. We cannot betray the expectations of the public. As we have decided to carry on playing, I would like to make us the team that can take gold. In order to do that, practice will have to be severe and we'll have to challenge each other to our very human limits."

After bowing to the pressure, Daimatsu believed the Nichibō Kaizuka corporate team would be the Japanese national Olympic team, but the JVA insisted there should be a 'mixed' team. In the selection committee for the Olympic team, ten out of twelve players were chosen from Nichibō and the remaining two required were selected from other corporate teams. ${ }^{34}$ Kasai records that Daimatsu was very upset that two of his Nichibō players had to be dropped from the Olympic team. ${ }^{35}$

The pressure intensified massively on the women's volleyball team leading up to 1964. After they defeated the Soviets in 1962 and became world championships it became headline news across Japan, and almost a fait accompli for the forthcoming Olympics in the minds of the Japanese national press. For Kasai and the other players it must have felt as though there was little option other than to win. Kasai recorded how the press commentary in 1962 after their win over the Soviet team included statements such as "victory is confirmed for the Tokyo Olympics' and 'the brilliant achievement by the Oriental Witches decides public mood for a gold medal win by the Witches at the forthcoming Olympic Games'. Kasai also describes how after the 1962 win it was much more difficult, as world champions, to be 'chased' by the Soviet team rather than 'to chase' and that she felt immense pressure to deliver. ${ }^{36}$ When the team later won gold, she recorded that she was glad to win as a response to that public expectation.

As the Olympics progressed in October 1964, the Japanese public were buoyed by medal results, particularly in judo, athletics and wrestling, but on the afternoon of $23^{\text {rd }}$ October a 
Japanese judo competitor expected to win the gold medal was defeated by a Dutch competitor. This increased the pressure on the expectations of a gold medal in the women's volleyball final which was scheduled for later that same day. By late afternoon, people and taxis were disappearing off the streets across Japan, and the telephone switchboard operated by Nippon Telegraph and Telephone Corporation almost ground to a halt, as everybody rushed to be near a television set to watch the final of the women's volleyball. To say that a gold medal was expected from the Japanese team was an understatement. One of the team members had commented anxiously the previous day that, 'if we lose, we might have to leave the country'. ${ }^{37}$ Such was the public expectation and pressure amounting for the players. At 7 pm that evening, the excitement emanating from the Komazawa indoor sports hall in Tokyo began its broadcast on televisions across Japan. The Japanese and the Soviet teams arrived on the court. With Soviet players as tall as $184 \mathrm{~cm}$ in height, they looked a physically imposing presence vis-'a-vis the Japanese team, with Kasai the tallest Japanese player at $174 \mathrm{~cm}$. The Japanese team won the first two sets decisively: 15-11 and 15-8. In the third set they were leading 13-6, but then as the pressure of winning the gold became closer to reality they began to lose points consecutively. When the score reached 14-13, Daimatsu requested a time-out to talk to his team. After play resumed, the Japanese served the ball and an over-the-net foul from a Soviet player secured the elusive fifteenth point and served up Olympic history. The 4,000 spectators in the auditorium all leapt up with thunderous applause, while the six players on the court stood shocked for a moment then cried and embraced each other. ${ }^{38}$

This final match was, in the end, a decisive victory for Kasai and her team, winning in three straight sets (final score 15-11, 15-8, 15-13). ${ }^{39}$ As a new sport, it was the first gold medal in women's volleyball in Olympic history. For Japan, it was also the first gold medal in a women's event in 28 years. ${ }^{40}$ But it was also the end of an Olympic Games that had put Japan back on to the international stage after their WWII defeat, and a sporting event that served to unite and restore the spirit of a nation and its people. For the Japanese women's volleyball team, it was the end of a journey that had taken them from playing the sport as young employees in a corporate team to representing their nation at the first and only Summer Olympics ever to have been held in Japan. For Kasai and her team mates, this journey hadn't been as easy as that decisive victory might suggest. Kasai later described the moment the whistle blew in that final match, and her team mates cried and came to hug her. She describes how she was choked with deep emotion, and filled with tears but that she tried not to cry 'until her mission as team captain finished'. ${ }^{41}$ While receiving the gold medal in the awards ceremony and watching the Japanese flag raised with the national anthem, she felt very emotional and moved, and very glad that she had been able to meet the expectations of the Japanese people. She records that, if she had quit two years previously, she would not have felt that deep emotion nor received the gold medal, and was happy that she had made the decision to continue. ${ }^{42}$ However, the emotion of the win and the decision to continue to that Olympics had clearly been difficult for her. Cited in the Yomuri newspaper the day after the victory, Kasai confessed that she had the feelings of any 'normal young woman'. She told how a good friend of hers from high school had come to the competition with her daughter to cheer on the team. Seeing her friend with an 8-year-old daughter, Kasai said she felt mixed feelings, thinking that if she had not continued with competitive volleyball she too might have been in the audience with a child like her friend. Kasai's father had passed away in July of that year and had wanted to see her as a bride. Commenting on the victory after the match, Kasai was quoted as saying: 'I would like to choose a happy life as a woman from tomorrow, with all my experience of volleyball up until tonight'. ${ }^{43}$ 
This seemingly innocent statement offers great insight into the gender dynamics at play at this point in Japanese history. Although the textile companies had long utilised young female labour, this had always been viewed within prescribed notions of women and work, notably the history of 'motherhood protection' in Japan. Women could be employed, and were increasingly sought after from the 1960s as Japan encountered a labour shortage, but Japanese employers were always mindful of their maternity, which included their potential or future maternity. Young women employed in the textile industry were 'temporary' employees until they could fulfil their ultimate role in life as wives and mothers. ${ }^{44}$ Even women employed primarily for their sporting abilities would not have been immune to this prevailing view, though there are some conflicting dynamics at play when reflecting on the story of Kasai and her team-mates. On the one hand, their gender was in many ways ignored by Daimatsu who enforced his strenuous training regime and flouted all notions of motherhood and menstrual leave when it came to the preparation of the team for the 1964 Olympics. On the other hand, Japanese female athletes were by this point in time viewed within a complex social debate on femininity and nationalism. ${ }^{45}$ Moreover it should not be forgotten that these Olympic volleyball athletes were company employees and would have been keenly aware of their future maternal roles, as this was a key discourse within educational programmes for all their female employees rolled out by the textile companies at this time. Corporate responsibility for maternity could also extend to helping employees find suitable marriage partners.

After the Olympic victory, it is fair to say that Kasai became something of a national celebrity in Japan. Although her wish was to retire immediately after the Olympics, she played in subsequent friendly games against Romania and in China, and recorded that she was busy attending a lot of celebratory events. ${ }^{46}$ Daimatsu was also frequently appearing on TV and giving lectures, but he took his 'paternalistic duties' very seriously and was also making time to visit the parental homes of his team in order to help their families seek potential marriage partners for his players. Soon after the Olympic victory, Daimatsu and the team met the then Prime Minister, Sato Eisaku, whereupon Kasai reportedly mentioned her inability to marry due to her years of volleyball training and Daimatsu asked for the PM's help in introducing potential husbands for his players. ${ }^{47}$ Kasai was then famously introduced to an officer from Japan's Self Defence Force, arranged by Prime Minister and Mrs Sato, and went on to marry him. In January 1965, Daimatsu announced his decision to retire from Nichibo Corporation. He was asked to stay on as the manager of the national team after the Olympic victory, but he refused the offer. Kasai and five other players then announced their resignations the following day once Daimatsu's resignation had been accepted by Nichibō. ${ }^{48}$ Even after these official resignations and retirements, the Japanese media continued to follow the lives of the players, particularly with regard to their possible marriage moves. Kasai recorded how she was followed around by the media all the time after the Olympics, that it was difficult to meet up with her fiancé without the media noticing, and that six months after the Olympics she was still so busy every day that she felt she had little time to prepare for her impending wedding. ${ }^{49}$ Kasai's wedding to Nakamura Kazuo in May 1965 made national media headlines. The Japanese prime minister and his wife attended the wedding as official matchmakers and he gave a speech at the wedding commenting 'I think Kasai Masae is more known than me in Japan'. The newlywed couple were interviewed on television following their ceremony, and on their honeymoon to Hakone were followed around by several cars from the Japanese media. ${ }^{50}$

In 1965, Daimatsu was asked to help establish a national volleyball team in China by the Chinese Prime Minister, Zhou Enlai. Kasai also went to China with Daimatsu to help train 
both men's and women's national teams. It has been suggested that this move had the flavour of both a political and international business strategy. Prior to WWII, Nichibō and the other prominent textile firms had established many factories in China, and by the 1970s Japan's domestic textile industry had declined rapidly and was 'hollowing out' of Japan. Keen for relations with China to recover, companies such as Nichibō were poised to reestablish business in China, and it is suggested that Daimatsu was used as part of a negotiation deal, exchanging his coaching abilities for the opportunity to build factories in China. A Japanese academic argues that this may be one 'fate of corporate sports', 51 as the Chinese team would later go on to be world number one in the sport. A few years later, in 1968, Daimatsu was elected as a Liberal Democrat Member of Parliament. He served until an election defeat in 1974 when he returned to volleyball, becoming technical advisor to a corporate team for the Japanese retailer Ito-Yokado Co., Ltd. He also received honorary citizenship from Utatsu-cho, where the 'Daimatsu Cup' volleyball tournament has been held in the town ever since. Daimatsu died in 1978 at only 57 years of age. He was long viewed after the Olympic gold medal victory as a national hero in Japan. Inducted into the Volleyball Hall of Fame in 2000, his record notes that he was 'the coach who revolutionised training for all women's sports'. ${ }^{52}$ Contemporary academic and media debates on sports training in Japan continue to refer to his legacy. ${ }^{53}$

\section{Women's Volleyball in Japan after 1964}

The popularity of volleyball, particularly as a sport for women, grew immensely following the 1964 Olympics victory by the 'Oriental Witches', with the Japanese mass media playing an influential role. The sport was fictionalised in two popular series, ' $V$ is our Sign' and 'Attack No.1' which both started as cartoon series (manga) in rival girls' magazines in 1968. They were both launched in 1969 as television series, and 'V is our Sign' in particular became a hit drama, with a wide audience ranging from children to adults, and boasting average viewing ratings of $32.3 \% .^{54}$ Kasai commented in interview that in 1964 she could not have imagined the widespread popularity that the sport would gain in the aftermath of the victory. Daimatsu's book 'Follow Me' also became a best seller, with volleyball not only a 'medal promising' sport but now a growing social phenomenon in Japan. ${ }^{55}$

Less obvious than the popular dramatisation of the series, but, I would argue, even more influential and long-lasting, was the spread of the sport to women of all ages in Japan, notably with the establishment of 'mama-san volleyball' (mother's volleyball). Previously the domain of young women, after the 1964 victory it became an acceptable and accessible sport for older, married Japanese women as well. Kasai commented in interview that, prior to the Olympics, Japanese housewives (shufu) concentrated on housework and looking after children, reflecting that it was 'unthinkable' that a housewife would engage in sports or have a job or hobbies outside the home. After the Olympics, however, women of all ages were inspired to take up the sport and mama-san volley clubs for housewives sprung up across Japan. Kasai commented that 'volleyball doesn't need much equipment - just a ball and a net', and that 'mama-san volleyball was an opportunity to both play and socialise'. The term 'housewife volleyball' (kateifujin barēbōru) is the formal name for the sport in Japanese, but mama-san volleyball (mama san barēbōru) is the more popular term and widely used. One Japanese author argues that mama-san volleyball has been the key sport for married women in Japan, and that while it did liberate them from their isolated domestic life, it has also served to emphasise and perpetuate the notion that their primary role is as 'housewives' ${ }^{56}$ 
The popularity of the sport for women spread rapidly throughout the post-war economic growth years in Japan, as leisure activities became more acceptable amidst a growing and affluent Japanese middle-class, with teams for married and older women most prominently organised by PTA groups and by local government community centres across Japan. In 1970 a mama-san volleyball national competition was launched by the JVA in cooperation with sponsorship from the Asahi Newspaper, and the mama-san clubs are still popular throughout Japan today, with Kasai noting that there are many women who started playing mama-san volleyball in the early years that are still playing today. There are national competitions held annually in Japan, and the mama-san volleyball is split into various leagues including veteran leagues defined by age categories: Isoji for the over 50's, Kotobuki for the over 60's and Ofuku for the over 70's. Although for many women across Japan, mama-san volleyball is a leisure or hobby activity, the top ' $V$-league' competition is a serious national league and includes players who have retired out of competitive corporate or other teams. Indeed the title mama-san volleyball is now somewhat misleading. Players in the V-league are required to be 35 years or older in age but it is not a requirement that they be married or indeed be a mother. Women and sport has evolved in Japan since the 1960s but in many ways is still located within gender contradictions and definitive notions of motherhood. Female athletes, who are not mothers, can compete in the mama-san volleyball league. Being a female athlete in any sport is no longer a role restricted to a time before marriage and motherhood. And yet contemporary Japanese female athletes who do have children, are often referred to as 'athlete mums' (mama san senshu).

Women's volleyball continued to be a competitive sport in Japan after the 1964 games at both the corporate and national levels in Japan, though there has been some notable changes over the decades. With the decline of textiles as a key industry in Japan from the 1970s, not surprisingly the domain of competitive women's volleyball no longer resided in corporate teams from the textile companies. Nichibō, later renamed Unitika Ltd., dissolved its corporate team in $2000 .^{57}$ It seems evident that without the support of the textile companies, particularly Nichibō, there would not have been the gold medal victory in women's volleyball in 1964. The subsequent decline of that industry led many to speculate that perhaps the glory days of corporate sports and women's volleyball might have ended in Japan. ${ }^{58}$ Indeed, Japan's economic problems since the 1990s has meant that many sports have had to shift their emphasis from corporate teams to sports teams comprising other forms of sponsorship. However, at the same time I would argue that competitive women's volleyball in Japan remains a 'corporate sport' in nature, albeit with the type of corporations having changed over time, moving from the textile firms, to electronics firms and now increasingly to firms in the service sector. ${ }^{59}$ Current women's volleyball teams competing nationally, from which Japan's national team draws players, include teams such as the Toray Arrows (owned by a chemical fibre company) and the Hisamitsu Springs team (owned by a pharmaceutical company). ${ }^{60}$ As the formerly prominent textile company teams all faded in strength, particularly in the 1990s, in some respects so did the international strength of the Japanese women's volleyball team. After the 1964 gold medal victory, the Japanese women's team won the silver medal in Mexico in 1968 and in Munich in 1972. They then went on to win the gold medal for the second time in Montreal in 1976. However, after taking the bronze medal in Los Angeles in 1984, the team's ranking continued to go down and went into a slump. They failed to qualify for the Sydney Olympics in 2000 for the first time since 1964. After missing the Sydney Games, they competed at Athens in 2004 and Beijing in 2008, both times losing in the quarter finals. However, after twenty eight years without an Olympic medal, the Japanese women's volleyball team took the bronze medal at last year's London Olympics in 2012. At a press conference held in London on $12^{\text {th }}$ August, the team manager 
Manabe Masayoshi noted the 'triumph of teamwork' and commented that the strength of Japanese women's volleyball lies in the solidarity of their team members and in persistent pursuance of techniques, because with an average height of 1.75 metres the Japanese have the lowest height out of all the 12 teams that competed in London. ${ }^{61}$ Indeed this remark harks back to the commentary that surrounded the Japanese team in the 1960s. Kasai, 79 years of age in August 2012, was also quoted in the Japanese press on the day of the bronze win, congratulating the team and commenting that after twenty eight years since the last medal the Japanese team was getting steadily stronger after a long slump period. ${ }^{62}$

Kasai continued to be heavily involved in volleyball after retiring from the Olympic and the Nichibō team. In 1965, she and other ex- Nichibō players formed Fuji Club, a team which went on to win the national tournament in 1965 and $1966 .{ }^{63}$ In 1973, a weekly television programme called Saturday Deportes began, in which six of the original 'Oriental Witches' played against various amateur mama-san volleyball teams, which helped contribute to the popularity and spread of the sport for Japanese women of all ages during these years. ${ }^{64}$ During the 1980s and 1990s, Kasai was a coach for various teams, including some in the mama-san league. She was Vice-Chair of the JVA in 2003-4, charged with strengthening Japanese women's volleyball, and was the head of all the Japanese women's sports teams at the 2004 Olympic Games in Athens. She was inducted into the Volleyball Hall of Fame in 2008. At the end of our interview in May 2012, Kasai offered her own reflection on her life.

The gold medal changed my life a lot. My subsequent forty-eight years have been a really happy life. Many people who watched TV that day and cheered for the volleyball team in the Olympics have now passed away. But I am still remembered by a lot of people when I attend volleyball classes and activities all over Japan. The fact that the Olympics were held in Japan had a huge impact. People all over Japan watched the games on TV. Even people who didn't have a TV watched them somewhere. The viewing rate of our final match is still unbeatable. It has been forty-eight years since then, but I am still recognised everywhere - in the train, on the streets or in the department store. I'm very grateful. I think that I am the luckiest volleyball player in the world.

\footnotetext{
${ }^{1}$ Robin Kietlinski, Japanese Women and Sport: Beyond Baseball and Sumo (London: Bloomsbury Academic, 2011) documents the participation of Japanese women in various sports from the early 20th century to the present day, and locates it within a broader discussion of Japanese women as 'delicate' beings and Japan as a nation of lagging gender equality. William W. Kelly, 'Adversity, Acceptance, and Accomplishment: female athletes in Japan's modern sportsworld', Asia Pacific Journal of Sport and Social Science, Vol.2:1, p1-13, 2013 argues that both Japanese success at the Olympics and the history of corporate sponsorship of sport have contributed to the development of women in sports within Japanese society.

${ }^{2}$ Reference to the 1964 victory as a notable event in Japanese sporting history and the Nichibō 'Witches' team as having had a symbolic impact on women's sporting history can be found in Allen Guttmann and Lee Thompson, Japanese Sports: A History (Honolulu: University of Hawaii Press, 2001, p198-99 \& 223), Joseph Maguire and Masayoshi Nakayama, Japan, Sport and Society: tradition and change in a globalizing world (London: Routledge, 2006, p114), Kietlinski, 2011, p90, and Kelly, 2013, p3\&7-8

${ }^{3}$ The history of how Japanese textile companies approached the employment of a predominantly female workforce has been well documented. See Janet Hunter, Women and the Labour Market in Japan's Industrialising Economy: the textile industry before the Pacific War (London: RoutledgeCurzon, 2003), Helen Macnaughtan, Women, Work and the Japanese Economic Miracle: the case of the cotton textile industry, 1945 75 (London: RoutledgeCurzon, 2005) and Elyssa Faison, Managing Women: disciplining labor in modern Japan (University of California Press, 2007)

${ }^{4}$ Masahiko Sawano, Joshi Barēbōru no Eikō to Zasetsu, (Hokkai Gakuen University, 2008, p159)

${ }^{5}$ See Guttmann and Thompson, 2001, p131

${ }^{6}$ Sawano, 2008, p159

${ }^{7}$ Sawano, 2008, p159-60
} 


\footnotetext{
${ }^{8}$ Sawano, 2008, p161

${ }^{9}$ Macnaughtan, 2005, p188

${ }^{10}$ Nobuko Shibuya (director), Le Prix de la Victoire, Grand Prix, Short Film Category, Cannes, 1964

${ }^{11}$ I use two key sources for this personal perspective. The first source is her memoir style book: Masae Kasai, Okāsan no Kinmedaru (Tokyo: Gakken, 1992) only available in Japanese, and to my knowledge not utilised in any academic literature either in Japanese or English to date. The second source is a semi-structured interview I conducted in Japanese with Kasai Masae on 30th May 2012, the first interview she said she had given to a nonJapanese academic. Kasai is still widely known in Japan and, at 79 years of age at the time of interview in 2012, was still involved with volleyball and had a sharp and lively memory for the detail of the 1964 events and her role in them. For the full record of my interview with Kasai, see Helen Macnaughtan, 'An interview with Kasai Masae, captain of the Japanese women's volleyball team at the 1964 Tokyo Olympics', Japan Forum, 24:4, 2012, 491-500

${ }^{12}$ Kasai, 1992, p181

${ }^{13}$ Kasai, 1992, p182

${ }^{14}$ Kasai, 1992, p183. It was still common practice at that time in Japan for prospective employers to make home visits and speak to families, particularly when offering employment to young girls.

${ }^{15}$ Kasai, 1992, p183-4

${ }^{16}$ Kasai, 1992, p184-6

${ }^{17}$ The majority of young female textile employees at this point in history in Japan were recruited out of middle school rather than high school like Kasai, who was clearly recruited specifically for her volleyball skills. Special recruits such as Kasai were often assigned administrative rather than factory floor work and had volleyball training as a key daily focus, but they all did continue to undertake work for the company so can be considered true amateur players right up until the Olympics in this sense.

${ }^{18}$ The big Japanese textile companies at this time housed the majority of their regular workers on factory grounds in dormitory accommodation. See Macnaughtan, 2005.

${ }^{19}$ Kasai, 1992, p197-8

${ }^{20}$ Kasai 1992, p187

${ }^{21}$ For a discussion of employment strategies in the Big Ten companies see Macnaughtan, 2005. The corporate history of sports in Nichibō is documented in Unichika, Unichika Hyakunenshi, Ge, 1969-1989 (Osaka, 1991, p527-548)
}

${ }^{22}$ See Takuya Fukuda, 'Kigyō Supōtsu ni okeru Unei Ronri no Henka ni kansuru Shiteki Kōsatsu - Nihonteki keiei, amachua, masumedia no hattatsu o bunseki shiza toshite', Ritsumeikan Keieigaku, 49.1, May 2010. Although Unichika no longer has a corporate volleyball team, it still records the 1964 Tokyo victory as a key milestone in its corporate history and includes this in its CSR reports, accessible at:

http://www.unitika.co.jp/e/csr/pdf/csr2010.pdf

${ }^{23}$ Sawano, 2008, p162

${ }^{24}$ Age based hierarchy is certainly a strong cultural consideration in Japan and may well be the key reason for her captaincy, but I would suggest that her Japanese sense of 'modesty' in interview may have diffused any other contributing reasons for her selection

${ }^{25}$ See Sandra Collins, The 1940 Tokyo Games: The Missing Olympics: Japan, the Asian Olympics and the Olympic Movement. (London: Routledge, 2006)

${ }^{26}$ See Christian Tagsold, Die Inszenierung der kulturellen Identität in Japan: Das Beispiel der Olympischen Spiele Tōkyō 1964 (Munich: Iudicium Verlag, 2002)

${ }^{27}$ Rio Otomo, 'Narratives, the Body and the 1964 Tokyo Olympics', Asian Studies Review, Vol. 31, June 2007, p117-132

${ }^{28}$ Kon Ichikawa (director), Tokyo Olympiad (1965, 170 minutes)

${ }^{29}$ Sixteen gold medals is the highest number of gold medals ever achieved by Japan at the Summer Olympics, on par with the sixteen gold medals won at Athens in 2004, where they were $5^{\text {th }}$ in the medal rankings.

${ }^{30}$ NHK, 50 Years of NHK Television, Available at

http://www.nhk.or.jp/digitalmuseum/nhk50years_en/history/p12/ (accessed 16 April, 2013)

${ }^{31}$ Kasai, 1992, p72-3

${ }^{32}$ Kasai, 1992, p 59

${ }^{33}$ Kasai, 1992, p 72

${ }^{34}$ One player was selected from Kurabō (a textile firm) and one from Yashica (a camera manufacturer).

${ }^{35}$ Kasai, 1992, p 82-3

${ }^{36}$ Kasai, 1992, p64-5

${ }^{37}$ Sankei News Archive, Osaka no 20 Seki (31), Kaiten Reshiibu 'Tōyō no Majo' Sekai ni Kōfun to Kandō. 20 October 2011. Available at http://sankei.jp.msn.com/west/west_sports/news/111020/wsp11102010010002n1.htm (accessed 7 August, 2012) 
${ }^{38}$ The Yomiuri newspaper's morning edition on $24^{\text {th }}$ October 1964 described the victory moment as the 'moment of ecstasy' Yomiuri Online, Ano Hi Ano Toki: 10 gatsu 23 nichi, 1964 nen 'Tōyō no Majo' ga Kinmedaru Kakutoku. 23 October, 2011. Available at http://www.yomiuri.co.jp/otona/history/ october/20111011-OYT8T00803.htm (accessed 8 August, 2012)

${ }^{39}$ The final results in the women's volleyball competition at the 1964 Tokyo Olympics were, in winning order: Japan, USSR, Poland, Romania, USA and South Korea. Although the Japanese men's volleyball team was not expected to win a medal, they took the bronze medal.

${ }^{40}$ Maehata Hideko won gold in the 200 metres women's breaststroke at the 1936 Berlin Olympics, making her the first Japanese woman to win an Olympic gold medal

${ }^{41}$ Kasai, 1992, p90

${ }^{42}$ Kasai, 1992, p90-91

${ }^{43}$ Yomiuri Shinbun, 24th October, 1964

${ }^{44}$ For more on 'motherhood protection' within the textile industry see Macnaughtan, 2005, p6-7 \&188-195

${ }^{45}$ See Kietlinski, 2011, p89-93, and the discussion of Olympic track star Hitomi Kinue in Dennis J. Frost, Seeing Stars: Sports Celebrity, Identity, and Body Culture in Modern Japan. (Cambridge: Harvard University Press, 2010, p109-150)

${ }^{46}$ Kasai, 1992, p33

${ }^{47}$ Sawano, 2006, p162

${ }^{48}$ Kasai, 1992, p35

${ }^{49}$ Kasai, 1992, p24\&33

${ }^{50}$ Kasai, 1992, p50-53

${ }^{51}$ Sawano, 2008, p163

${ }^{52} \mathrm{http} / / /$ www.volleyhall.org/daimatsu.html (accessed 20th August, 2013)

${ }^{53}$ For example, see Japan Times, Severe sports training methods became taibatsu in time, $2^{\text {nd }}$ June 2013. Available from: http://www.japantimes.co.jp/sports/2013/06/02/baseball/severe-sports-training-methodsbecame-taibatsu-in-time/\#.UhhQtt9wYdU (accessed $20^{\text {th }}$ August 2013). For an in-depth discussion of the history of Japanese sports coaching see Aaron L Miller, Discourses of Discipline: An Anthropology of Corporal Punishment in Japan's Schools and Sports. (Institute of East Asian Studies, Japan Research Monograph 17, August 2013)

54 'V is our Sign' (the V standing for Victory) centred around a fictional women's volleyball team, loosely based on the Olympic team. It was created as a cartoon series by Shiro Jinbo and Akira Mochizukiin, requested by the publisher of a girls' magazine in response to the popularity of 'Attack No.l' created by Chikako Uraga which had begun earlier that year in a rival publication. In 1969, 'V is our Sign' became a televised drama series, while 'Attack No.l' begun as a televised animated series, and later in 2005 re-launched as a drama series.

${ }_{55}^{55}$ Sawano, 2008, p143-4

${ }^{56}$ See Haruko Takaoka, 'Katei Fujin Supōtsu Katsudō ni okeru 'Shufusei' no Saiseisan: barēbōru no hatten katei to seido tokusei o chüshin ni', Research of Physical Education 53(2), 391-407, 2008-12-10, Japanese Society of Physical Education, Health and Sport Sciences.

${ }_{58}^{57}$ Nichibō changed its name to Unitika in 1969, following a merger with Nippon Rayon.

${ }_{58}^{58}$ Sawano, 2008, p162

${ }^{59}$ A broader discussion of changing corporate sponsorship for both male and female sports teams in Japan can be found in Hiroyuki Kurosaka and Sumie Ōyama, 'Kigyō Chīmu no Hensen kara Nihon Keizai ga mieru: barēbōru Nihon rīgu o rei toshite', Seikatsu Kagaku Kenkyū, 17, 1995, p47-55

${ }^{60}$ When Unichika ended their team in 2000 all their team members moved to the Toray team, but have since all retired.

${ }^{61}$ Yomiuri Online, 'Mottomo shinchō hikui barējoshi, kono tsuyomi de 'dō' kakutoku'. Available from: http://www.yomiuri.co.jp/olympic/2012/news/ballgame/volley/1/20120812-OYT1T00571.htm (accessed 15th August, 2012)

${ }^{62}$ Sanspo News, 2012. 'Joshi barē ni 28nen buri dōmedaru! Kankoku ni setsujoku'. Available from: http://www.sanspo.com/london2012/news/20120811/vol12081119390005-n3.html (accessed 12th August 2012)

${ }^{63}$ Kasai, 1992, p98

${ }^{64}$ Kasai, 1992, p138\&140. The programme was called Doyō Deporute in Japanese 